\title{
Governance in Comprehensive Partnership Between Indonesia and Malaysia
}

\author{
Ludiro Madu \\ Department of International Relations \\ Universitas Pembangunan Nasional "Veteran" Yogyakarta \\ Yogyakarta, Indonesia \\ ludiro.madu@upnyk.ac.id
}

\author{
Aryanta Nugraha \\ Department of International Relations \\ Universitas Pembangunan Nasional "Veteran" Yogyakarta \\ Yogyakarta, Indonesia
}

\author{
Suryo Wibisono \\ Department of International Relations \\ Universitas Pembangunan Nasional "Veteran" Yogyakarta \\ Yogyakarta, Indonesia
}

\begin{abstract}
This paper suggests that comprehensive partnership could eliminate existing potential conflicts between Indonesia and Malaysia. Involving more non-state actors, promoting non-political, informal, and direct links could strengthen Indonesia-Malaysia relation. Those characteristics of comprehensive partnership would also increase governance in bilateral relations. Therefore, comprehensive partnership could be an effective mode in building sustainable Indonesia-Malaysia relations.
\end{abstract}

Keywords-governance, comprehensive partnership, Indonesia, Malaysia, non-state actors

\section{INTRODUCTION}

Bilateral relations between Indonesia and Malaysia can be portrayed as dynamics in nature, which involved both conflict and cooperation. The increasing possibility for a problematic bilateral relation comes to surface when both have direct borders, language similarity, shared cultural values, religious commonality (Islam), and similar historical roots as sources of the rift [1]. However, this tendency, of course, is not meant to underestimate closer cooperation between both neighboring countries. Until the change of leadership in Indonesia from President Susilo Bambang Yudhoyono ---popularly known as SBY--- to President Joko Widodo or Jokowi in October 2014, many bilateral problems have been unsettled satisfyingly. Many necessary attempts in finding possible solutions and anticipating potential risks in future has been conducted, but it seems that Indonesia's government has to find alternative way in managing its bilateral relations to Malaysia.

This paper seeks to promote the importance of a comprehensive partnership for bilateral relations between both neighboring countries. It offers bilateral model of comprehensive partnership for finding out appropriate solutions in mediating the existing bilateral conflicts and developing optional policies in managing sustainable bilateral relations. In general, discussion on Indonesia and Malaysia relation will, firstly, focus on elaborating several bilateral conflicts which led to attempts for identifying sources of conflicts. Various efforts which both countries have undertaken for resolving the conflicts, both in government-to- government and community-to-community levels will also be take into account. Finally, this paper explains the importance of involving as many as communities from both countries for implementing comprehensive partnership in order to build a more sustainable bilateral relation which is based on the Indonesian perspective. This partnership also closely connects to the importance of governance in Indonesia's bilateral relations to Malaysia.

The increasing of democratization and economic development have driven revitalization of Indonesia's foreign policy in the form of a more active and assertive in international stage. During Susilo Bambang Yudhoyono's Presidency, the country increasingly take advantage of the world's third-largest democracy and home to the world's largest community of Muslims for its its diplomacy in international stage [2]. Furthermore, Rizal Sukma asserted that Indonesia's government has employed three main strategies in its foreign policy [3]. The first strategy is to deepening Indonesia's role in driving the establishment of regional community in Southeast Asia. Indonesia's enthusiasm in promoting multilateralism can be seen in its activism in various institutions, such as G20, World Trade Organization (WTO), Asia Pacific Economic Cooperation (APEC), Association of South East Asia Nations (ASEAN), ASEAN plus Three (APT), ASEAN Regional Forum (ARF), and East Asia Summit (EAS).

Second strategy is strengthening bilateralism to several key countries as an important part o fits multilateralism strategy. In many cases, Indonesia made use various multilateral forum for improving its bilateral cooperations. Recently, the format of bilateralism has been developed in the concept of partnership. There are, at least, two forms of bilateral partnership, i.e. strategic partnership and comprehensive one. Until now, Indonesia has developed strategic partnerships to China, India, Jepang, and South Korea. The last strategy is making sure of Indonesia's global commitment as an active contributor in finding solution over various problems for the issues of economic crisis, energy and food security, and climate change. Indonesia signed comprehensive partnership to the United States [4], Australia, and European Union. 
Within the frameworks of strategic partnerships and comprehensive partnerships, recent Indonesia's foreign policy and diplomacy seeks to approach sustainable bilateral relations with certain countries [5]. Both strategic partnerships and comprehensive partnerships focusses on a targeted agenda with a clear priority and concret outcome which leads to a measurable and predicted partnership [6]. Furthermore, strategic partnership also shows a friendly relations which is based on an specific agreement to explore ideas and institutionalize cooperation on a set of shared issues in a longterm bilateral relations. On the importance of these partnerships, both strategic and comprehensive partnerships are significant parts of a pro-active Indonesia's diplomacy. In turn, both models of diplomacy could increase Indonesia's strategic position and role in building stability and peace with other countries, including Malaysia.

Interestingly, Indonesia and Malaysia have not considered either one of them. Nevertheless, bilateral relation between Indonesia and Malaysia has led to strategic partnership. This tendency can be found in the dominance of state-to-state actors relations which consequently build friendly relations among government officials. On the other hands, the strategic partnership does not give much room for community-tocommunity relations. Lack of community interaction easily creates lack information about others and could potentially form misunderstanding among communityes of both countries. The strategic partnership tend to give priority to bilateral relations on specific sectors which emphazise on certain parts of the whole relations between several government's institutions or departments of two countries. Consequently, interaction between communities is not as important as those of governments which lead to potential rift among society in both countries.

Building comprehensive partnership between Indonesia and Malaysia would connects various sectors for bilateral cooperation. Both countries cannot limit their cooperation on a selected and targeted sector which led to the form of strategic partnership. Instead of developing strategic partnership, the idea of building comprehensive partnership is of much importance for eliminate gap on the on-going problematic issues and finding a thorough and sustainable solution for the dynamic bilateral relations. Comprehensive partnership between Indonesia and Malaysia also strengthens the fact that both societies have an increasingly easy access of connecting each other. The progress of information, communication, technology, and transportation has put both societies into a frequent interaction. The increasing communication between two communities has also posed the importance of people in building a non-state-led relations between Indonesia and Malaysia.

\section{RESEARCH METODOLOGY}

Using descriptive qualitative method, this paper aims at describing bilateral relations between two countries, particularly through a case study between Indonesia and Malaysia. The case study is of importance for analyzing the possibility of developing comprehensive partnership as a model for bilateral relation between both countries. By understanding existing bilateral conflicts and bilateral attempts which both countries have undertaken, this paper suggest Indonesia and Malaysia to take comprehensive partnership. This partnership depends much on community to community relations which would enhance bilateral relations beyond government officials.

\section{RESULTS AND DISCUSSION}

\section{A. Conflict Sources and Patterns}

Commonalities between neighboring countries should give more room for building peaceful bilateral relations. This thought usually explains Indonesia and Malaysia bilateral proximities from the perspective of collective or shared identity and similarity of geographic origin. The shared identity is frequently coined as 'saudara serumpun' relations [7] which equals to the term of kinship or "brother-sister" (abang-adik) relations. This shared identity has resulted in positive and negative impact to the bilateral relations of boht countries.

Furthermore, the practice of both countries interaction shows their inability in using the most advantage of those abovementioned factors. Since 2005, Indonesia and Malaysia involved in many issues of cultural claims. The latest was Malaysia's claim on traditional dance Tor-tor and musical instrument Gondang Sembilan (nine drums) which originated from Indonesia's Mandailing tribe. An Indonesia's English language daily, the Jakarta Post, describes the issue, as follows "The latest spat over national heritage involving Indonesia and Malaysia only affirms the vulnerability of ties between the two neighbors concerning the same cultural roots to even a nonissue of provocation". Malaysia played a song known as being of Indonesian origin, "Rasa Sayange", in its tourism industry advertisement, then moved on to claim batik [8], the Reog dance, ---which originated from an East Java town of Ponorogo--- and West Java's bamboo musical instrument angklung, and also Pendet dance of Bali. Cultural heritage become one of many sources between the two nations' problem over the past few years. Many Indonesia's cultural 'products' which Malaysia has claimed and easily become politically sensitive for Indonesian public in particular. Until now, there is almost no case of Indonesia's claims toward Malaysia's cultural products.

During the SBY government, Indonesia has involved in several incidents of geographic conflicts. Both countries shared territorial borders, both hard (land) and soft (sea and air) ones [9]. The issue of Karang Unarang's border unexepectedly came up in the last days of President SBY in power. When President Jokowi assumed his power, he met Malaysian Prime Minister Najib with the aim of finding solution on the border issue [10]. Border problem has been intensified until now with no satisfying solution bilaterally. On land border, both have more or less $1,000 \mathrm{~km}$ line border in Kalimantan or Borneo Island which have been too risky in creating bilateral rows. Further problems related to border issue also increased bilateral tense, especially those related to traditional and non-traditional security issues.

Traditional security issues are closely related to issues which result in threats for military and national security, such 
as the moving of Indonesia's border lines. As for the nontraditional security issues cover the problems which have indirect impact to national security and interest, such as human trafficking, illegal logging, illegal fishing, traditional illegal border crossings, sea piracy, illicit drugs trafficking, arms smuggling, and terrorism. To some extent, nontraditional security issues are not just a bilateral, but it is also a transnational problem in Southeast Asia [11]. The case of terrorism shows the use of border regions between Thailand (Southern region), Malaysia (territorial water of Langkawi and Penang), the Philippines (Southern region such as Zamboanga and Davao of Mindanao), and Indonesia (Nunukan, islands of Sangihe Talaud), which consequently required all of these four countries to cooperate for solving the problem.

Most of the cases which put Indonesia and Malaysia into risky relations is non-traditional. Indonesia's government, of course, still have authority to manage and arrange the settlement process of the problems. However, both governments should have strong commitment to invite their community/society to take part in finding alternative solutions. Involving community is of importance for widening people's participation so that community could have opportunity to apply check-and-balances mechanism on their governments' policy on promoting peaceful bilateral relations.

\section{B. Community-based Bilateral Relation}

Implementation of the comprehensive partnership closely connects to the increasing issue of governance in diplomacy, including in Indonesia's case. By involving as many as communities in its foreign relations, governance in Indonesia's bilateral relation can be conducted in a more transparant means by involving participation of its community/society and by managing it in an accountable procedures. The governance of bilateral relations in framework of comprehensive partnership does not merely put the role of government in dominance position, but it also invites community [12] ---particularly those who stay both temporarily and permanently in Malaysia--- to take active role in increasing Malaysian people understanding on Indonesia (see table 1).

Table 1. Organizations of Indonesian Societies in Malaysia [13]

\begin{tabular}{|c|c|c|}
\hline No. & Name & Website \\
\hline 1 & $\begin{array}{l}\text { Persatuan Pelajar Indonesia (PPI) di } \\
\text { Malaysia }\end{array}$ & ppi-malaysia.org/ \\
\hline 2 & $\begin{array}{l}\text { Perhimpunan Masyarakat Indonesia } \\
\text { (PERMAI) }\end{array}$ & $\begin{array}{l}\text { permai- } \\
\text { malaysia.blogspot.com }\end{array}$ \\
\hline 3 & Kagama Cabang Khusus Malaysia & $\begin{array}{l}\text { kagamamalaysia.wordpre } \\
\text { ss.com/ }\end{array}$ \\
\hline 4 & $\begin{array}{l}\text { Pimpinan Cabang Istimewa } \\
\text { Muhammadiyah (PCIM) Malaysia }\end{array}$ & $\begin{array}{l}\text { malaysia.muhammadiyah } \\
\text {.or.id/ }\end{array}$ \\
\hline 5 & $\begin{array}{l}\text { Pengurus Cabang Istimewa Nahdlatul } \\
\text { Ulama (PCINU) }\end{array}$ & $\begin{array}{l}\text { www.nu.or.id/post/read/1 } \\
\text { 5880/pcinu-malaysia- } \\
\text { dilantik }\end{array}$ \\
\hline 6 & $\begin{array}{l}\text { Ikatan Ahli Teknik Perminyakan } \\
\text { Indonesia (IATMI) }\end{array}$ & iatmi.or.id \\
\hline 7 & Komite Nasional Pemuda Indonesia & $\begin{array}{l}\text { bpknpi.org/pelantikan- } \\
\text { bp-knpi-mlaysia/ }\end{array}$ \\
\hline 8 & $\begin{array}{l}\text { Paguyuban Solidaritas Masyarakat } \\
\text { Jawa (PASOMAJA) }\end{array}$ & - \\
\hline 9 & Ikatan keluarga Madura di Malaysia & $\begin{array}{l}\text { wafimuhaimin.wordpress. } \\
\text { com/2014/01/10/orang- }\end{array}$ \\
\hline
\end{tabular}

\begin{tabular}{|l|l|l|}
\hline & & madura-di-negeri-orang/ \\
\hline 10 & $\begin{array}{l}\text { Forum Komunikasi Masyarakat } \\
\text { Muslim Indonesia (FORKOMMI) }\end{array}$ & - \\
\hline 11 & $\begin{array}{l}\text { Ikatan Pekerja Muslim Indonesia } \\
\text { (IPMI) }\end{array}$ & - \\
\hline 12 & Indonesian Trade Association & $\begin{array}{l}\text { www.facebook.com/Indo } \\
\text { nesia-Trade-Association- } \\
192759057579840 /\end{array}$ \\
\hline
\end{tabular}

There are at least two conflict sources which have remarked bilateral relationship between Indonesia and Malaysia, as follows: government and community rows. In the government level, the rows came from the incapability of both governments in taking advantage of commonalities. Lack of political will on both governments could be the main issue since each government does not have different priorities in each foreign policy. Although both countries are founding state of Association of Southeast Asia Nations (ASEAN), they seem to have a few similarities of perceptions in solving bilateral problems.

In the level of community, both have been in the different levels of democratization. In the post-Suharto era, Indonesia has experienced much more rapid process of democracy rather than Malaysia. Democratization gives more complication on the nexus of government-society relation in domestic context. Consequently, Indonesian community or society has much more liberal and fluid nature in its relations to government. Whilst Malaysian community has to deal with its more or less stagnant democracy which led to less political liberalization [3]. Within this democratic political structure, Indonesian society has more political structures of opportunity to express their oppositional insights toward Indonesian government rather than Malaysian community [3]. Consequently, this political process influences political culture of both communities in responding their own national issues, including bilateral problems between their countries.

Within this context, community-to-community relations seems to be an important option to find out solution of bilateral problems, particularly between Indonesia and Malaysia. The on-going problematic relations show that most of bilateral rifts have occurred in the levels of IndonesianMalaysian governments (G-to-G) and Indonesian communityMalaysian government. Most of on-going bilateral interactions also took place in those two levels. While Indonesian community has a few access of interaction with Malaysian community, especially in discussing sensitive issues on the national security. Therefore, the use of cultural commonalities as a mean for building community-to-community could generate a different way of resolving bilateral rows.

It seems that government-to-government mechanism for resolving bilateral rows is more plausible, but the problem mostly rested in the slow and unclear process which made the problems unsolved. Ambalat issue [9] is just one example of the on-going unsolved problems. Although both countries have reached a certain understanding about certain issues of bilateral conflict, it does not mean the conflict has been solved completely. Both countries have also established Memorandum of Understanding (MoU) on mediating the problems of migrant workers. However, it does not mean that the problem related to migrant workers would be easily 
solved. Another ineffective settlement is Joint Border Committee (JBC) that plays role in resolving border problems between Indonesia and Malaysia. Several incidents in the sea and land borders tended to worsen bilateral relations, including recent case in Tanjung Datu and Camar Bulan of West Kalimantan. Among those bilateral conflicts, most are unfinished. Only Sipadan and Ligitan was settled by the ICJ mediation. Still many more issues seem to be potentially risky for both countries.

Even history shows the incompetence of both governments in building sustainable positive relation, especially in the link between domestic politics and foreign policy in Indonesia. Indonesia's democratization has not only resulted in new national political orders, but also have an impact on foreign policy making [14]. Jorn Dosch stated that

The influence of non-governmental actors in the foreign policy arena is prominently related to the way in which regime accountability constraints the government's latitude of decision-making in foreign affairs. In an authoritarian state regime, accountability tends to be low because the procedures for power transfer are not institutionalized. The continuity of a regime is not linked to the legislative process, elections, judicial decision, or even the regime's performance. Hence, accountability does not impose a signicant limitation on foreign policy making in authoritarian polities. In contrast, democratization increases regime accountability and, as a result, restricts the regime's leeway in determining and implementing foreign policy goals.

Within this context, Indonesia's foreign policy has not been a mere domain of the state or the ruling government. However, foreign policy arenas have opened up its room for a various groups of community in Indonesia. This political structure is likely to be luxurious goods for Malaysian community. With its less stagnant domestic political structure, Malaysia's government would not give any 'room of maneuver' for the influence of its society on Malaysia's foreign affairs [3]. At the same time, Indonesian community has more vocal opinion in voicing out their interests in foreign affairs. Therefore, Malaysian government has more frequent diplomatic protests to its Indonesian counterpart on Indonesian society's demonstration in front of Malaysian embassy in Jakarta, rather than the other way around.

On community-to-community level, Indonesia has more interests in taking initiatives. This idea was promoted by the Indonesia's Minister of Foreign Affairs, Dr. Marty M. Natalegawa, in asserting Indonesia's commitment for aggressively wagging peace "...through partnership rather than competition; through the building of bridges rather than by accentuating differences." [5]. Although those strategies are the domain of the government, Indonesian community could take a lead in building a more concrete forum for resolving bilateral problems. Both communities must also understand the importance of their initiatives in preventing potential conflicts between their countries.

Until the second year of the Jokowi government, many bilateral problems have not achieved any satisfying solutions. The claims of cultural heritage did not come into surface and attract public sensitivity anymore in both countries.
The issue of Indonesian migrant workers is still problematic, but both countries has agreed to make bilateral commitment for their better life condition in Malaysia. One of problems which frequently influences bilateral relations is border issue, both in maritime and land territories. Nationalist tendencies in Indonesia under President Jokowi unlikely lead to strengthen the existing bilateral problems [15]. The fact that President Jokowi visited Malaysia twice and PM Najib went to Jakarta three times have increase optimism on finding bilateral solutions.

While bilateral problems are still prevalent in government level, community-to-community relations seems to be more impressive and prospective. More art and cultural festivals have been conducted in Kuala Lumpur and its surrounding cities, which is not limited to the commemoration of Indonesia's Independence day anymore. The ease of transportation attracted Malaysian people to visit various cities in Indonesia which have direct flight from Malaysia. Enthusiasm of Malaysian people for visiting Bandung has resulted in an idea of establishing 'Little Bandung' in Kuala Lumpur in early 2016. Many Indonesian universities have institutional cooperation with their partners in Malaysia. Better quality and international networking of Malaysian universities have increasingly encouraged University-to-University relations. Universities from both countries have also designed various schemes of cooperation in the form of student or lecturer visit, exchange study program, double degree, and other academic activities. These various activities in community-to-community level have undoubtedly increased interaction which indirectly would give impact to governmentto-government relations

\section{CONCLUSION}

Comprehensive partnership is of increasingly importance for developing bilateral relations between Indonesia and Malaysia. The fact that the bilateral relation would also involve community participation has shown that it will provide more advantage on the partnership rather that the strategic one. By enhancing community and people initiatives in strengthening the existing state-oriented relations, a comprehensive partnership can be developed with the purpose of increasing understanding between both communities in Indonesia and Malaysia. Therefore, the idea of building a comprehensive partnership would hopefully result in a more sustainable and stable bilateral relation between Indonesia and Malaysia.

\section{REFERENCES}

[1] Baiq L.S.W. Wardhani, "Trend in Indonesia-Malaysia Bilateral Relations in Post-Suharto Period", Indonesian Journal of Social Sciences, Vol. 1, No. 1, 2009

[2] Ann Marie Murphy, "Democratization and Indonesian Foreign Policy: Implications for the United States", Asia Policy, Number 13, 2012, pp. 83-111

[3] Khadijah Md. Khalid and Shakila Yacob, "Managing MalaysiaIndonesia relations in the Context of Democratization: the Emergence of Non-State Actors", International Relations of the Asia-Pacific, Vol. 12, No. 3, 2012, pp. 355-387.

[4] Ehito Kimura, "Indonesia in 2011: A Glass Half-Empty", Asian Survey, Vol. 52 No. 1, 2012, pp. 186-194 
[5] Marty M. Natalegawa, "Aggressively Waging Peace: ASEAN and the Asia Pacific", Strategic Review, Vol. 1, No. 2, November-December 2011, p. 4

[6] Jinn Winn Chong, ""Mine, yours or ours?": The Indonesia-Malaysia disputes over shared cultural heritage", SOJOURN: Journal of Social Issues in Southeast Asia, Vol. 27, No. 1, 2012.

[7] F. Abdullah, "The Rumpun Concept in Malaysia-Indonesia Relations", The Indonesian Quarterly, Vol. 21, No. 2, 1983, p.185.

[8] Marshall Clark, "The Politics of Heritage: Indonesia-Malaysia cultural contestations", Journal of Indonesia and the Malay World, Vol. 41, No. 121,2013

[9] Ludiro Madu, “Ambalat Netwar antara Indonesia-Malaysia, 2005 Refleksi Teoritis Mengenai Hubungan Internasional di Era Internet" (Ambalat Netwar between Indonesia-Malaysia, 2005: Theoretical Reflection on International Relations in the Internet Era"), Journal of Global \& Strategis, Vol. 2, No. 1, 2008.

[10] . Dewa Gede Suadika Mangku and Herman, "Indonesian Government Authority in Terms of Border Management with Other Countries",
International Journal of Business, Economics, and Law, Vol. 10, No. 4, 2016.

[11] Eric Tagliacozzo, "Border Permeability and the State in Southeast Asia: Contraband and Regional Security", Contemporary Southeast Asia, Vol 23, No. 2, 2001, pp. 254-274

[12] Iis Gindarsah, "Democracy and Foreign Policy-Making in Indonesia: A Case Study of the Iranian Nuclear Issue, 2007-08”, Contemporary Southeast Asia: A Journal of International and Strategic Affairs, Vol. 34, No. 3, 2012 , pp. 416-437

[13] Indonesia Embassy at Kuala Lumpur, Pemutakhiran Data Organisasi Masyarakat Indonesia di Malaysia (Renewing Data of Indonesian Society Organization in Malaysia), http://www.kbrikualalumpur.org/ index.php/indeks/pengumuman/87-pemutakhiran-data-organisasimasyarakat-indonesia-di-malaysia

[14] Jörn Dosch, "The Impact of Democratization on the Making of Foreign Policy in Indonesia, Thailand and the Philippines," Südostasien aktuell No. 5, 2006, p. 42

[15] Edward Aspinall, "The New Nationalism in Indonesia", Asia \& the Pacific Policy Studies, Vol. 3, No. 1, 2015, pp. 72-82 